\title{
Analysis of the IgVH genes in T cell-mediated and antibody-mediated rejection of the kidney graft
}

\author{
Cristiana Bellan, ${ }^{1}$ Teresa Amato, ${ }^{1}$ Mario Carmellini, ${ }^{2}$ Monica Onorati, ${ }^{1}$ \\ Alessandro D'Amuri, ${ }^{1}$ Lorenzo Leoncini, ${ }^{1}$ Maria Teresa del Vecchio ${ }^{1}$
}

${ }^{1}$ Section of Pathological

Anatomy, Department of Human Pathology and Oncology,

University of Siena, Siena, Italy

${ }^{2}$ Section of Surgery,

Department of Surgery and Bioengineering, University of Siena, Siena, Italy

\section{Correspondence to}

Professor Lorenzo Leoncini, Section of Pathological

Anatomy, Department of Human

Pathology and Oncology, Via delle Scotte, 6, 53100 Siena, Italy; leoncinil@unisi.it

Accepted 5 October 2010 Published Online First 20 November 2010

\section{ABSTRACT}

Aims Grafts have been shown to be sites where the alloimmune response develops in a direct interaction between the targeted tissue and the immune effectors. An important issue in renal rejection is B cell infiltrate that may contribute to the development or persistence of rejection. Analysis of gene-expression patterns also provides a window on the biology and pathogenesis of renal allograft rejection.

Methods To better understand the role exerted by B cells in a renal acute rejection, the authors analysed the IgVH gene repertoire in six cases of transplanted kidneys with acute $T$ cell-mediated rejection (TCMR), three of which were associated with antibody-mediated rejection (ABMR). Results The authors found mutated and unmutated sequences, without any evidence of clonal relationships, in all patients with TCMR alone and in two of the three cases with both acute TCMR and ABMR. The remaining patient showed glomerular inflammation and thrombosis, with diffuse C4d glomerular and peritubular capillary deposition, and hypermutated $V$ region genes.

Conclusions These results suggest that there is more than one pathway to the onset and perpetuation of CD20 $(+)$ B cells infiltration in acute rejection; furthermore, the CD20 (+) B cells' clonal expansion may be responsible for a more severe pattern of $A B M R$, through immune-mediated tissue damage.

\section{INTRODUCTION}

The involvement of antibodies in rejection of organ transplants is increasingly recognised as a relevant pathomechanism. In acute cellular liver allograft rejection, hepatic B lymphocytes and plasma cells as well as B-cell-activating cytokines have recently been described, indicating that, in addition to $\mathrm{T}$ cells, antibody-mediated mechanisms might be involved. It is well known that the success of kidney transplantation is dependent on the genetic and immunological compatibility of the grafted organ with the recipient.

Biopsy samples from patients with acute kidney allograft rejection that are indistinguishable on conventional histological analysis reveal extensive differences in gene expression, which are associated with differences in immunological and cellular features and clinical course. It is therefore amazing that, in renal rejection, there are few data on the stage of differentiation of B cell infiltrates and their role in the development or persistence of rejection. ${ }^{1-10}$

The analysis of the immunoglobulin variable heavy chain region $(\mathrm{IgVH})$ genes had a great impact on the understanding of $\mathrm{B}$-cell response in various inflammatory and autoimmune diseases but had never been applied to kidney allograft rejection. ${ }^{11-17}$ It has been applied to acute humoural and cellular liver allograft rejection, suggesting that locally accumulated B cells and their antibodies might be involved in IgG-mediated complement activation. ${ }^{18}$

Thus, our aim was to analyse the $\operatorname{lgVH}$ gene repertoire in transplanted kidneys in six cases of acute T cell-mediated rejection (TCMR), three of which were associated with antibody-mediated rejection $(A B M R)$ in order to better understand the role played by $\mathrm{CD} 20(+) \mathrm{B}$ cells in renal acute rejection.

\section{MATERIALS AND METHODS \\ Patients and tissue}

Percutaneous renal needle biopsy guided by ultrasound (G18) was obtained from six recipients of deceased donor first kidney transplants performed at the Siena University Hospital between 2004 and 2006. The clinical data are resumed in table 1 . The clinical course was characterised by suspected early acute rejection. The time of biopsy ranged from 15 days to 20 months after transplant.

Patients 1, 2 and 3 showed the presence of antiHLA antibodies, revealed by the Luminex technique performed at the time of biopsies.

Renal biopsies met the Banff criteria for adequacy ${ }^{19}$; we used the Banff 2007 classification for allograft pathology and score. ${ }^{20}$ All biopsies were interpreted by two pathologists with expertise in renal allograft pathology.

Immunohistochemical stains were performed on $3 \mu \mathrm{m}$ thick sections of each block employing the streptavidin-biotin method. After being dewaxed and rehydrated, sections were incubated with 3\% $\mathrm{H}_{2} \mathrm{O}_{2}$ in Tris buffered saline (TBS) to inhibit endogenous peroxidase, then processed with different methods for each antibody. In order to show $\mathrm{CD} 4(+)$ the sections were unmasked with Wcap buffer (pH 6.0 for $40 \mathrm{~min}$ at $98^{\circ} \mathrm{C}$; Bio-Optica, Milan, Italy) and incubated with antihuman CD4 monoclonal antibody (clone 4B12; 1:50; Menarini, Florence, Italy). To improve the detection of CD8, CD20, CD27, CD68 and Ki67, we performed a pretreatment in citrate buffer $(0.01 \mathrm{M}, \mathrm{pH}$ 6.0) with a microwave oven at $750 \mathrm{~W}$ for $5 \mathrm{~min}$, for three cycles; sections were incubated with antihumanCD8 monoclonal antibody (clone CD8-144B; 1:50; Dako, Milan, Italy), CD20 (clone Ab-1 (126); 1:150; Neo Markers, Freemont, California), CD27 (clone 137B4; 1:50; Novocastra, Newcastle, UK), CD68 (clone KP1, 1:50; Dako) and Ki67 (clone SP6, 1:200; NeoMarkers, Freemont, California, USA). For CD38 
Table 1 Clinical data

\begin{tabular}{|c|c|c|c|c|c|c|c|c|c|}
\hline No & Gender & $\begin{array}{l}\text { Age of } \\
\text { recipient } \\
\text { (years) }\end{array}$ & $\begin{array}{l}\text { Age of donor } \\
\text { (years) }\end{array}$ & Primary disease & Mismatch & Intention to treat & $\begin{array}{l}\text { Maintenance of } \\
\text { immunosuppressive } \\
\text { regimen }\end{array}$ & $\begin{array}{l}\text { Time from } \\
\text { transplant } \\
\text { to biopsy }\end{array}$ & $\begin{array}{l}\text { Previous episode of } \\
\text { acute graft rejection }\end{array}$ \\
\hline 1 & $\mathrm{~F}$ & 60 & 71 & $\begin{array}{l}\text { Atherosclerosis } \\
\text { renovascular disease }\end{array}$ & 6 & $\begin{array}{l}\text { Anti-CD25, steroids, CyA, } \\
\text { MMF }\end{array}$ & $\begin{array}{l}\text { Steroids, CyA, } \\
\text { MMF }\end{array}$ & $\begin{array}{l}28 \text { days } \\
\text { (graft failure) }\end{array}$ & - \\
\hline 2 & $\mathrm{~F}$ & 55 & 66 & ADPKD & 3 & $\begin{array}{l}\text { Anti-CD25, steroids, CyA, } \\
\text { sirolimus }\end{array}$ & $\begin{array}{l}\text { Steroids, CyA, } \\
\text { sirolimus }\end{array}$ & $\begin{array}{l}152 \text { days } \\
\text { (5 months) }\end{array}$ & - \\
\hline 3 & $\mathrm{~F}$ & 55 & 69 & ADPKD & 5 & $\begin{array}{l}\text { Anti-CD25, steroids, tacrolimus, } \\
\text { MMF }\end{array}$ & $\begin{array}{l}\text { Steroids, tacrolimus, } \\
\text { MMF }\end{array}$ & 20 months & - \\
\hline 5 & $M$ & 44 & 17 & ADPKD & 3 & $\begin{array}{l}\text { Anti-CD25, steroids, CyA, } \\
\text { sirolimus }\end{array}$ & Steroids, CyA, sirolimus & 52 days & - \\
\hline 6 & M & 22 & 63 & Unknown & 4 & $\begin{array}{l}\text { Anti-CD25, steroids, CyA, } \\
\text { sirolimus }\end{array}$ & Steroids, CyA, sirolimus & $\begin{array}{l}119 \text { days } \\
\text { (4 months) }\end{array}$ & - \\
\hline
\end{tabular}

ADPKD, autosomal dominant polycystic kidney disease; CyA, ciclosporin $A$; MMF, mycophenolate mofetil.

(clone38C03; 1:50; Thermo Scientific, Fremont, California), slides were preincubated with EDTA buffer $(0.05 \mathrm{M}$, pH 8.0) for $30 \mathrm{~min}$ at $98^{\circ} \mathrm{C}$. For CD21 (clone 1F8, 1:10, Dako), the immunoperoxidase technique was performed after antigen retrieval with protease $0.4 \%$ in Tris buffered saline (TBS) buffer for $10 \mathrm{~min}$ at $37^{\circ} \mathrm{C}$. The biotinylated secondary link universal antibodies were associated with Streptavidin-horseradish peroxidase (HRP, Dako Cytomation, Milan, Italy) and revealed with DAB (Dako Cytomation LSAB +System-HRP). For C4d, pretreatment with citrate buffer $(0.01 \mathrm{M}, \mathrm{pH} 6.0)$ in a microwave oven at $750 \mathrm{~W}$ for $5 \mathrm{~min}$ (three cycles) was followed by incubation with antihuman C4d polyclonal antibody (1:100; DBA, Milan, Italy). The Primary Antibodies Enhancer was associated with AP Polymer (UltraVision LP Detection System AP Polymer, LAB Vision) and revealed with fuchsin (Dako Cytomation).

Known positive controls (tonsil tissue) as well as negative controls (without primary antibody) were also stained in each run. ${ }^{21}$ The monoclonal antibodies and source used are shown in table 2

\section{Histology}

CD20(+) B cell infiltrate was distinguished in nodular and scattered distribution; nodular when clear dense clusters of CD20(+) B cells were present and scattered when at least a moderate $(++)$ number of $\mathrm{CD} 20(+) \mathrm{B}$ cells were present in the interstitial compartment.

In either the cortex or the medulla, the staining for C4d in peritubular capillaries (PTCs) and scoring of peritubular capillaritis (PTCs) were evaluated as recommended in the Banff 2007 classification. $^{20}$

Monocyte macrophages (CD68 (+), evaluated in glomeruli, PTCs and interstitium), T cells (CD3 $(+)$, CD4 $(+)$ and CD8 $(+))$ and plasma cells CD38 $(+)$ were graded using a semiquantitative score $(0=$ scanty to $3=$ conspicuous).

\section{Laser capture microdissection}

Clusters of CD20 (+) B cells were selected for microdissection from diffuse and nodular areas of B cell infiltrate. LCM was performed on $3 \mu \mathrm{m}$ thick immunostained tissue taken from the previously described formalin-fixed paraffin embedded tissue. ${ }^{20}$ Microdissected cells from the two different areas were isolated and transferred to a PCR test tube.

Clusters and isolated T cells were identified by their immunophenotype and served as negative controls. The cells were dropped in $10 \mu \mathrm{l}$ of PCR buffer $(50 \mathrm{mM} \mathrm{KCl} ; 10 \mathrm{mM}$ Tris- $\mathrm{HCl}$; $\mathrm{pH} 8.4 ; 0.01 \%$ gelatin) containing $200 \mu \mathrm{g} / \mathrm{ml}$ of proteinase $\mathrm{K}$ (Qiagen, Hilden, Germany). The isolated cells were covered with $50 \mu \mathrm{l}$ of mineral oil and digested at $37^{\circ} \mathrm{C}$ for $16 \mathrm{~h}^{21}$

\section{PCR, cloning and sequence analysis}

To avoid cross-contamination, all procedures prior to PCR amplification were performed in a room dedicated exclusively to this purpose and separated from the rooms where the subsequent steps were carried out. DNA quality control PCR, assessed by control gene primer sets according to the BIOMED 2 protocol, ${ }^{22}$ showed that all six gave an amplification of $300 \mathrm{bp}$ or more and thus sufficient intact DNA for successful amplification of the IgVH rearrangement.

To identify the rearranged segments of the variable heavy chain genes in cell clusters (CD20 (+) cells) an FR2BM PCR method (according to the BIOMED 2 protocol) and a nested PCR method were performed. In the FR2BM PCR, the set of primers consisted of seven oligonucleotides capable of annealing to corresponding VHFR2 segments (VH1FR2-VH7FR2). These $\mathrm{VH}$ primer sets were used in conjunction with a single $\mathrm{JH}$ consensus primer, designed to anneal to the most homologous $3^{\prime}$-end of the six JH segments. For the nested PCR method, in the first round of amplification a mix of six VH family specific framework 1 (FR1) primers and a consensus JH primer (LJH)

Table 2 Panel of antibodies used for diagnosis

\begin{tabular}{llll}
\hline Antibodies & Clone & Concentration & Source \\
\hline Anti-CD4 & Clone4B12 & $1: 50$ & Menarini, Florence, Italy \\
Anti-CD8 & Clone CD8 144B & $1: 50$ & Dako, Milan, Italy \\
Anti-CD20 & Clone Ab-1 (I26) & $1: 150$ & Neo Markers; Freemont, California, USA \\
Anti-CD68 & Clone KP1 & $1: 50$ & Dako, Milan, Italy \\
Anti-CD27 & Clone 137B4 & $1: 50$ & Novocastra, Newcastle, UK \\
Ki-67 & Clone SP6 & $1: 200$ & NeoMarkers, Fremont, California, USA \\
Anti-CD38 & Clone38C03 & $1: 50$ & Thermo Scientific, Fremont, California, \\
Anti-C4d & Clone C4d & $1: 100$ & USA \\
\hline
\end{tabular}


Table 3 Histopathological data

\begin{tabular}{|c|c|c|c|c|c|c|c|c|c|c|c|c|c|c|}
\hline No & $\begin{array}{l}\text { ACR Banff } \\
\text { score }\end{array}$ & $\begin{array}{l}\text { Histopathological } \\
\text { diagnosis }\end{array}$ & CD20 D N & CD3 & CD4 & CD8 & $\begin{array}{l}\text { C4d } \\
\text { scoring }\end{array}$ & $\begin{array}{l}\text { glomerular } \\
\text { C4d }\end{array}$ & C D68 I G & CD138 & ptc $\mathrm{Ne} \mathrm{M}$ & ATN & Oedema & $\begin{array}{l}\text { Capillary } \\
\text { thrombosis- } \\
\text { fibrinoid } \\
\text { necrosis }\end{array}$ \\
\hline 2 & 1a & $\begin{array}{l}\text { ATCMR (1a) + AABMR (II) } \\
\text { ('suspicious for') }\end{array}$ & $1+2+$ & $2+$ & $1+$ & $2+$ & $\mathrm{C} 4 \mathrm{~d} 2$ & - & $3+1+$ & ++ & ptc2 ++ & + & + & - \\
\hline 3 & $1 b$ & $\begin{array}{l}\text { ATCMR (Ib) + AABMR (II) } \\
\text { ('suspicious for') }\end{array}$ & $2+2+$ & $2+$ & $1+$ & $2+$ & $\mathrm{C} 4 \mathrm{~d} 2$ & - & $1+3+$ & +++ & ptc3 ++ & + & + & - \\
\hline $5^{*}$ & Borderline & ATCMR (borderline) & $1+2+$ & $1+$ & $1+$ & $1+$ & - & - & $2+2+$ & ++ & $\mathrm{ptc} 0$ & - & - & - \\
\hline 6 & $1 \mathrm{~b}$ & ATCMR (Ib) & $1+2+$ & $3+$ & $2+$ & $4+$ & - & - & $3+1+$ & + & ptc3 ++ & + & - & - \\
\hline
\end{tabular}

${ }^{*}$ CD21: negative

ACR, acute cellular rejection; ATN, acute tubular necrosis; AABMR, acute antibody-mediated rejection; ATCMR, acute T-cell-mediated rejection; D, diffuse; G, glomerular; I, interstitial; M, mononuclear cells; $\mathrm{N}$, nodular; $\mathrm{Ne}$, neutrophils; ptc, peritubular capillaritis.

were used. For reamplification, an aliquot of the first PCR from each case was amplified with a family-specific $\mathrm{VH}$ primer set for framework 2 (FR2) and a nested JH primer (VLJH).

PCR conditions and primers have been described in detail elsewhere. $^{23-25}$

The purified amplicons were cloned to the pCRII-TOPO vector (TOPO TA Cloning Kit; Invitrogen, Carlsbad, California) and were used to transform TOP 10 cells (Invitrogen) according to the manufacturer's instructions. A mean of at least 30 clones per case was sequenced in both directions with an ABI PRISM 310 Genetic Analyser (Applied Biosystems, Foster City, California). Sequences were compared against the GeneBank database (http//imgt.cines.fr) and the IgBlast database (http:// www.ncbi.nlm.nih.gov/igblast/). ${ }^{25} \mathrm{VH}$ genes were considered mutated if they differed by $\geq 1 \%$ from the corresponding germline sequence. In addition, sequences that showed the same $\mathrm{V}, \mathrm{D}, \mathrm{J}$, identical CDR3 and the same pattern and number of somatic mutations were considered as one. Finally, family trees were constructed by analysing shared and unique mutations occurring in sequences that were clonally related. ${ }^{26} 27$

Two methods were applied to assess antigen selection in productive and mutated $V_{H}$ gene immunoglobulin rearrangements as described previously. ${ }^{21} 28$ In other types of calculations, as described previously, ${ }^{23}$ the calculation of a reliable $p$ value $(p \leq 0.05)$ failed in the cases with a very low number of somatic mutations.

\section{RESULTS}

The patients' characteristics are summarised in table 1.

The clinical course of each patient was characterised by delayed function of the followed by early suspected acute rejection. Patients 1 and 4 showed graft failure with graft explantation.
The histopathological data for each case are shown in table 3. In all cases there was a scattered and nodular CD20 (+) B cell infiltrate (figure 1A,B). Some proliferating lymphocytes and a weak meshwork of CD21 dendritic cells were also detected in the nodules, but no clear germinal centre structures were identified; B-cells were intermingled with a minor component of CD4(+) T cells, and macrophages and plasma cells were present in the interstitium, but represented less than $10 \%$ in three cases. CD27 (+) B cells were scattered in the lymphoid infiltrates. C4d deposition was diffusely present in the PTCs in case 1 and focally present in cases 2 and 3 . It is worth noting that glomerular capillary endothelial deposition of C4d (figure 1C) and glomerular inflammation with thrombosis and fibrinoid necrosis were only present in case 1 (figure 2).

A total of $183 \mathrm{VH}$ sequences were amplified from the six cases of kidney allograft analysed. Eighteen of the 139 rearranged VH genes $(10 \%)$ were non-productive, being out of frame in five cases and containing a premature termination codon in CDR2 and CDR3 in three cases.

Of the nine potentially productive $\mathrm{VH}$ rearrangements amplified from $\mathrm{CD} 20(+) \mathrm{B}$ cells, six were unique, and three were shared by different sets of cells (see below).

Sequence analysis of the productive rearrangements of CD20 $(+) \mathrm{B}$ cells showed that they represented a mixed population of mutated and unmutated CD20 (+) B cells, with a great variability between cases. The average mutation frequency range in mutated cells was $4.11-21.55 \%$ and did not differ significantly among the various clinical and pathological categories of renal transplant (table 4).

Overall, the use of IgVH genes in our cases did not appear to show any bias towards the preferential use of a specific gene, since VH3 (the largest and most frequently used family) was
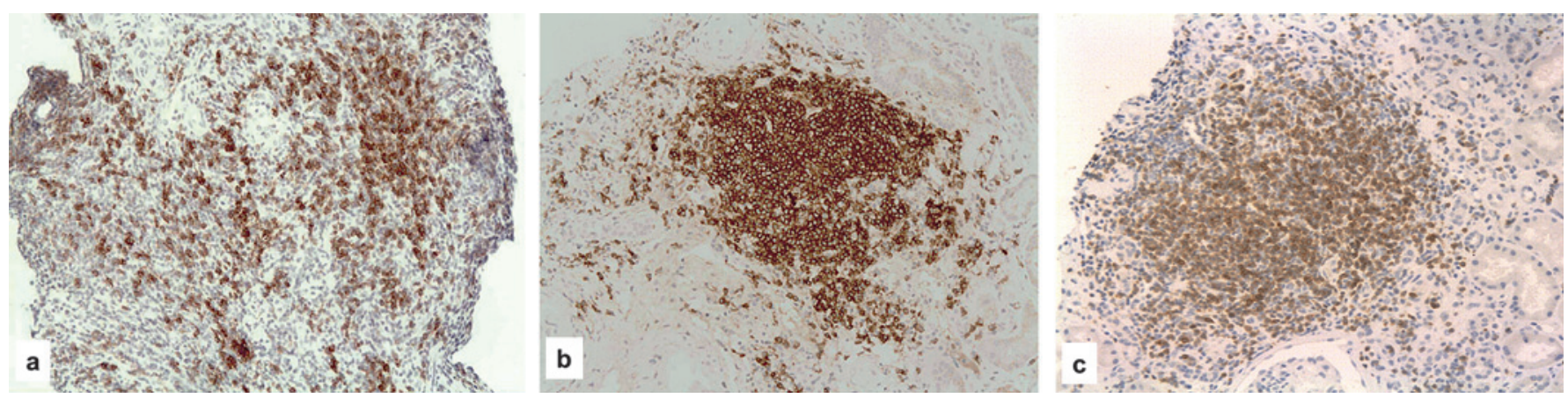

Figure $1 \mathrm{CD} 20(+) \mathrm{B}$ cell pattern of distribution. (A) Scattered CD2O(+) B cell infiltrate; (B) nodular CD20(+) B cell infiltrate; (C) CD4+ T cells in nodules (immunohistochemical stain, $(A, B): \times 100 ;(C) \times 200)$. 

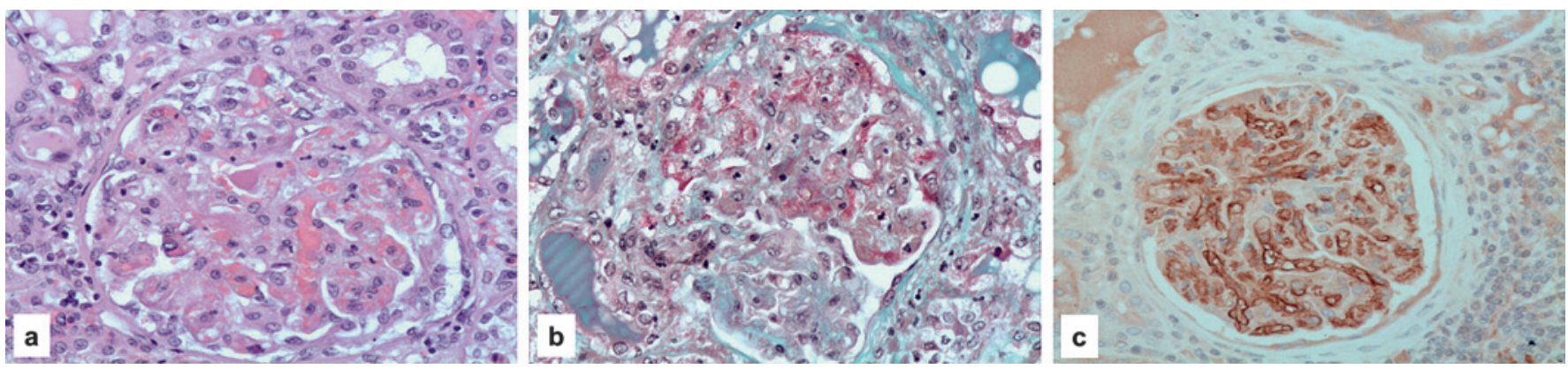

Figure 2 Histological picture of antibody-mediated rejection in case 1. (A) capillary thrombosis and cellular infiltration $(H \& E, \times 200) ;(B)$ capillary fibrinoid necrosis (Masson Trichromic $\times 200$ ); (C) diffuse capillary deposition of C4d (immunohistochemical stain $\times 100$ ).

Table 4 Molecular analysis of IgVH genes

\begin{tabular}{|c|c|c|c|c|c|c|c|c|}
\hline No & $\begin{array}{l}\text { Total no of clones } \\
\text { analysed }\end{array}$ & $\begin{array}{l}\text { Unique sequences/ } \\
\text { total }\end{array}$ & $\begin{array}{l}\text { Preferential IgVH } \\
\text { gene usage }\end{array}$ & $\begin{array}{l}\text { Mutated/ } \\
\text { total (\%) }\end{array}$ & $\begin{array}{l}\text { Mutation mean } \\
\text { (range) }\end{array}$ & $\begin{array}{l}\text { IgVH rearrangements } \mathrm{Ag} \\
\text { selected/total }\end{array}$ & $\begin{array}{l}\text { Ongoing } \\
\text { mutation }\end{array}$ & $\begin{array}{l}\text { Receptor } \\
\text { revision }\end{array}$ \\
\hline 1. & 22 & $9 / 22$ & VH3 & $6 / 9(67 \%)$ & $13.5(3-20)$ & $2 / 9$ & Yes & Yes \\
\hline 2. & 18 & $16 / 18$ & $\mathrm{VH} 3(3-66)$ & $13 / 16(81 \%)$ & $13(5-23)$ & $9 / 25$ & No & No \\
\hline 3. & 31 & $29 / 31$ & $\mathrm{VH} 3(3-23)$ & $15 / 29(52 \%)$ & $12.26(5-29)$ & $6 / 29$ & No & No \\
\hline 4. & 38 & $25 / 38$ & $\mathrm{VH} 3(3-23)$ & $9 / 25(36 \%)$ & $8.25(4-13)$ & $6 / 25$ & No & No \\
\hline 5. & 38 & $29 / 38$ & $\mathrm{VH} 3(3-30)$ & $21 / 29(73 \%)$ & $11.8(7-22)$ & $9 / 29$ & No & No \\
\hline 6. & 36 & $31 / 36$ & $\mathrm{VH} 3(3-15)$ & $20 / 31(65 \%)$ & $9.9(3-29)$ & $9 / 31$ & No & No \\
\hline
\end{tabular}

IgVH, immunoglobulin variable heavy.

found to be rearranged most often $(108 / 139 ; 78 \%)$ followed, in order, by VH4 (20/139; 14.5\%), VH5 (8/139; 6\%), VH2 and VH1. The use of $\mathrm{JH}$ segments also appeared to reflect the normal representation of peripheral antigen-experienced CD20 (+) B cells.
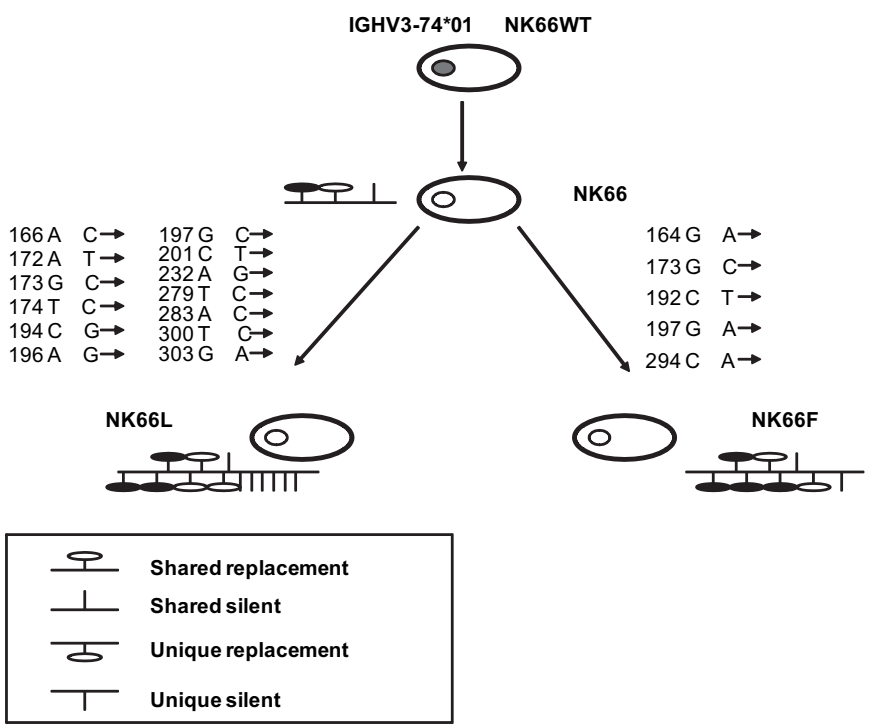

Figure 3 Clonal relationship between $\operatorname{CD20}(+)$ B cells in case one. The group of clonally related cells was composed of three cells obtained from three different single $\mathrm{CD} 2 \mathrm{O}(+) \mathrm{B}$ cells. The putative progenitors are depicted with grey nuclei, and the IgV gene rearrangement of the clonally related cells deriving from the progenitor is indicated above. Shared point mutations and acquired unique mutations are indicated above and below the line, respectively. Vertical bars depict $\mathrm{S}$ mutations, and lollipops depict $\mathrm{R}$ mutations.
The estimation of antigen selection in CD20 (+) B cells showed that the mutation pattern in most of their IgVH genes was negative for antigen-driven selection of a functional CD20 (+) B cell receptor. In fact, of 84 mutated $\operatorname{IgVH}$ genes, only 41 had an R/S ratio in the framework region (FWR) $3<1.5$ (11 out of 34 had an R/S ratio in the CDR2 >2.9) (table 4).

Regarding the three non-unique $\mathrm{VH}$ gene rearrangements amplified from case 1, all were productive and mutated and belonged to one group of three clonally related cells (clones $\mathrm{L}$ and F1). All three sequences showed a VH3-74*01/DH4-23*01/ $\mathrm{JH} 4^{*} 01$ usage but a different pattern of somatic mutations. These clones had virtually identical CDR3s and carried shared as well as unique somatic mutations, suggesting clonal expansion and intraclonal variation (figure 3 ). In the same case, sequences with an identical CDR3 rearrangement but a different $\mathrm{VH}$ usage were isolated; in fact, the sequence derived from clone A had a VH3-15*05/DH5-24*01/JH4*01 rearrangement, whereas the sequence derived from the clone B1 had a VH4-59*08/DH5$24 * 01 / \mathrm{JH} 4 * 01$ rearrangement.

This finding indicates that the CD20 (+) B cells analysed in our cases had revised the receptor specificity (ie, receptor revision). The clones listed in figure 4 illustrate the $\mathrm{VH}$ replacement occurring at the $3^{\prime}$ end of the FR3 embedded heptamer (TACTGTC). The $3^{\prime}$ FR3 embedded heptamer is displayed with a black background in the figure, and HCDR3s are boxed.

Note that the HCDR3s of the two clones are identical, whereas the VH segments upstream of the heptamer differ greatly between the two clones and resemble different germline genes.

\section{DISCUSSION}

Characterisation of the $\mathrm{B}$ cell population in acute rejection is fundamental for a better comprehension of the role exerted by these cells in graft tissue, as well as for a correct therapeutic 
Figure 4 DNA clones exhibiting variable heavy chain $(\mathrm{VH})$ replacement at the $3^{\prime}$ FR3 embedded heptamer. Two VH (VH 5-15, VH 4-59) clones from NK66 (A and B1) are aligned centrally with their most similar germline gene counterparts. The 3' FR3 embedded heptamer is displayed with a black background, and the HCDR3s are boxed. Nucleotide differences between the two clones are indicated by asterisks, and identities are indicated by dots.

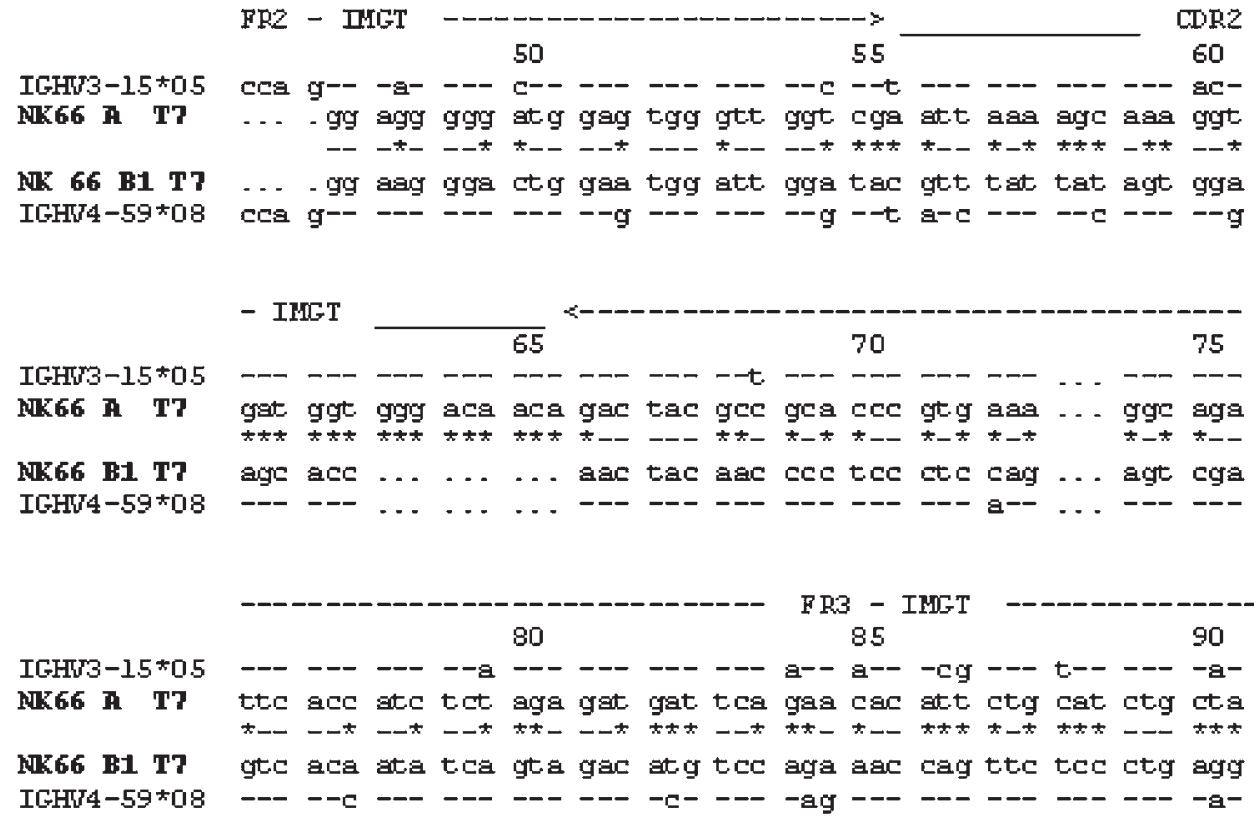

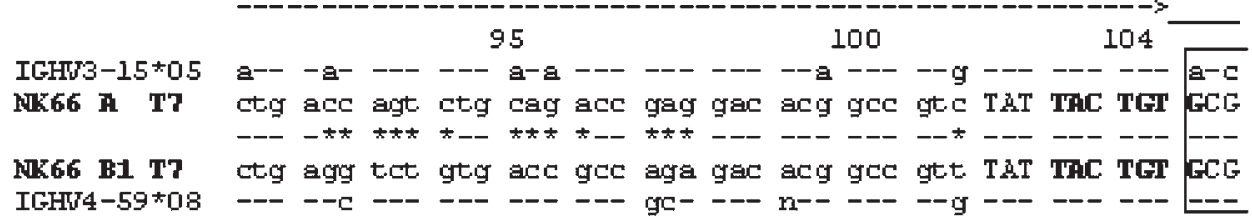

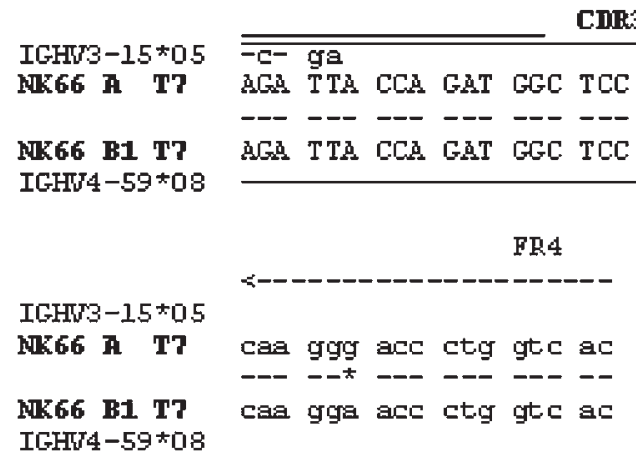

CDH3 - Tutri

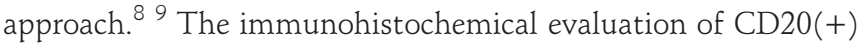
$B$ cells infiltrates in allograft biopsies has been suggested for potential treatment with anti-CD20 mAb (rituximab), ${ }^{29-31}$ as the presence of CD20(+) B cell infiltrates and CD38(+) plasmablasts in the kidney biopsies of patients undergoing acute renal allograft rejection has been reported to be associated with glucocorticoid resistance and a high risk of graft failure. ${ }^{1} 8932-40$

In our cases, we found lymphoid infiltration without any correlation with the clinical outcome. This is in line with recent reports that exclude any correlation of $\mathrm{B}$ cell infiltrates with the outcomes. $^{10-1232}$

Analysis of the IgVH gene repertoire has had a great impact on the understanding of $\mathrm{CD} 20(+) \mathrm{B}$ cell responses in lymphatic organs and has subsequently been applied to CD20(+) B cells in various inflammatory and autoimmune diseases and liver transplants but had never been applied to kidney allograft rejection. $^{15} 1841$

Our analysis of the VH-gene repertoire in two patients with both acute TCMR and ABMR and three patients with only
TCMR showed the presence of mutated and unmutated sequences without any evidence of clonal relationships. This finding indicates that CD20 (+) B cells become activated in peripheral lymphoid organs and subsequently migrate into renal tissue. $^{42}{ }^{43}$ Therefore, in these cases the small aggregates of $\mathrm{B}$ lymphocytes are the result of local accumulation rather than the consequence of local CD20 (+) B cells activation and differentiation. On the other hand, the finding of two identical rearrangements, which differed from each other by up to 13 somatic mutations in case 1 , speaks for antigen activation of B-cells and a clonal expansion within the renal tissue. The sequences allowed the construction of genealogical trees, which showed the stepwise accumulation of single somatic mutations during clonal expansion in the renal tissue (figure 3). The finding of mutated and clonally related $\mathrm{VH}$ genes in the lymphatic aggregates in case 1 seems to be in contrast with the absence of GC or GC-like structures in the same case, based on the assumption that $B$ cells undergo somatic hypermutation in the GC stage of differentiation. 


\section{Take-home messages}

In all patients but one with evidence of acute TCMR alone or associated with acute ABMR, CD2O(+) B cells expressed highly mutated $\mathrm{V}$ genes without any signs of clonal expansion.

- This finding showed that $\mathrm{Cd} 20(+) \mathrm{B}$ cells become activated in peripheral lymphoid organs and subsequently migrate into renal tissue where they result in a local accumulation rather than a consequence of a local activation and differentiation probably resulting in a non-pathological, unspecified bystander phenomenon.

- In the patient who had pathological evidence of glomerular inflammation, capillary thrombosis, fibrinoid necrosis and diffuse C4d peritubular capillary and glomerular capillary deposition, we detected clonal expansion, suggesting a pressure for antigen and permanent local activation of the ectopic lymphatic tissue. This may well induce a more severe pattern of ABMR, through immune-mediated tissue damage.

- More than one pathway is involved to the onset and perpetuation of $\mathrm{CD} 2 \mathrm{O}(+) \mathrm{B}$ cells infiltration in acute rejection.

However, recent evidence in animal models has revealed that normal B cells in extrafollicular areas of secondary lymphoid tissue are capable of responding to antigens and undergoing clonal expansion. Interestingly, in the same case, we were also able to demonstrate evidence of receptor revision, suggesting a pressure for the antigen in this context. The possible occurrence of secondary rearrangement of Ig genes in peripheral lymphoid tissues remains controversial, although several studies have reported the existence of this phenomenon. ${ }^{42}{ }^{43}$ In particular, receptor revision of $\mathrm{VH}$ genes has recently been proposed in both malignant lymphomas and normal human B lymphocytes. ${ }^{44-46}$ Thus, the ability to alter Ig expression by $\mathrm{VH}-\mathrm{DH}-\mathrm{JH}$ recombination might be a mechanism for the diversification of immune responses other than somatic hypermutation. ${ }^{47}{ }^{48}$ These findings suggest a remarkable genetic plasticity in subsets of antigenreactive $B$ lymphocytes in renal allograft.

In conclusion, our results provide evidence that there is more than one pathway to the onset and perpetuation of CD20 (+) B cell infiltration in acute rejection. In all patients but one with evidence of acute TCMR alone or associated with acute ABMR, CD20(+) B cells expressed highly mutated $V$ genes without any signs of clonal expansion; it is unclear whether this pattern contributes to tissue destruction or (more probably) represents a non-pathological, unspecified bystander phenomenon.

In contrast, in the patient that had pathological evidence of glomerular inflammation, capillary thrombosis, and fibrinoid necrosis and diffuse C4d peritubular capillary and glomerular capillary deposition, we detected clonal expansion, suggesting a pressure for antigen and permanent local activation of the ectopic lymphatic tissue. This may well induce a more severe pattern of ABMR, through immune-mediated tissue damage.

Competing interests None.

Patient consent Obtained.

Ethics approval Ethics approval was provided by the Azienda Ospedaliera Universitaria Senese, University of Siena.

Contributors MTdV, $L L$ and $C B$ performed the research, wrote the paper and analysed the experimental data. TA, MO, AD'A analysed the experimental data. MC collected the clinical data.

Provenance and peer review Not commissioned; externally peer reviewed.

\section{REFERENCES}

1. Zarkhin V, Li L, Sarwal M. 'To B or not to B?' B-cells and graft rejection. Transplantation 2008;85:1705-14.

2. $\mathbf{X u} \mathbf{X}$, Shi B, Cai M, et al. A retrospective study of plasma cell infiltrates in explanted renal allografts. Transplant Proc 2008;40:1366-70.

3. Martin F, Chan AC. Pathogenic roles of B cells in human autoimmunity; insights from the clinic. Immunity 2004:20:517-27.

4. Martin F, Chan AC. B cell immunobiology in disease: evolving concepts from the clinic. Annu Rev Immunol 2006;24:467-96.

5. Rodriguez-Pinto D. B cells as antigen presenting cells. Cell Immunol 2005:238:67-75

6. Carter RH. B cells in health and disease. Mayo Clin Proc 2006;81:377-84

7. Sarwal M, Chua MS, Kambham N, et al. Molecular heterogeneity in acute renal allograft rejection identified by DNA microarray profiling. $N$ Engl J Med 2003;349:125-38.

8. Hippen BE, DeMattos A, Cook WJ, et al. Association of CD20+ infiltrates with poorer clinical outcomes in acute cellular rejection of renal allografts. Am J Transplant 2005;5:2248-52

9. Lehnhardt A, Mengel M. Pape L, et al. Nodular B-cell aggregates associated with treatment refractory renal transplant rejection resolved by rituximab. Am J Transplant 2006;6:847-51.

10. Bagnasco SM, Tsai W, Rahman MH, et al. CD20-positive infiltrates in renal allograft biopsies with acute cellular rejection are not associated with worse graft survival. Am J Transplant 2007; 7:1968-73.

11. Doria C, di Francesco F, Ramirez CB, et al. The presence of B-cell nodules does not necessarily portend a less favorable outcome to therapy in patients with acute cellular rejection of a renal allograft. Transplant Proc 2006;38:3441-4.

12. Kayler LK, Lakkis FG, Morgan C, et al. Acute cellular rejection with CD20-positive lymphoid clusters in kidney transplant patients following lymphocyte depletion. Am J Transplant 2007:7:949-54.

13. Hwang HS, Song JH, Hyoung BJ, et al. Clinical impacts of CD38+ B cells on acute cellular rejection with $\mathrm{CD} 20+\mathrm{B}$ cells in renal allograft. Transplantation 2010;89:1489-95.

14. Tarlinton D. B-cell memory: are subsets necessary? Nat Rev Immunol 2006:6:785-90.

15. Kim HJ, Krenn V, Steinhauser G, et al. Plasma cell development in synovial germinal centers in patients with rheumatoid and reactive arthritis. $J$ Immunol 1999:162:3053-62.

16. Magalhaes R, Stiehl P, Morawietz L, et al. Morphological and molecular pathology of the $B$ cell response in synovitis of rheumatoid arthritis. Virchows Arch 2002:441:415-27.

17. Michaels PJ, Fishbein MC, Colvin RB. Humoral rejection of human organ transplants. Springer Semin Immunopathol 2003;25:119-40.

18. Moeller J, Krukemeyer MG, Morawietz L, et al. Molecular case report: IgVH analysis in acute humoral and cellular liver allograft rejection suggests a selected accumulation of effector B cells and plasma cells. Virchows Arch 2005; 446:325-32.

19. Racusen LC, Solez K, Colvin RB, et al. The Banff 97 working classification of renal allograft pathology. Kidney Int 1999:55:713-23.

20. Solez K, Colvin RB, Racusen LC, et al. Banff 07 classification of renal allograft pathology: updates and future directions. Am J Transplant 2008;8:753-60.

21. Bellan C, Lazzi S, Zazzi M, et al. Immunoglobulin gene rearrangement analysis in composite hodgkin disease and large B-cell lymphoma: evidence for receptor revision of immunoglobulin heavy chain variable region genes in Hodgkin-Reed-Sternberg cells? Diagn Mol Pathol 2002;11:2-8.

22. van Dongen JJ, Langerak AW, Bruggemann $M$, et al. Design and standardization of PCR primers and protocols for detection of clonal immunoglobulin and T-cell receptor gene recombinations in suspect lymphoproliferations: report of the BIOMED-2 Concerted Action BMH4-CT98-3936. Leukemia 2003;17:2257-317.

23. Tamaru J, Hummel M, Marafioti T, et al. Burkitt's lymphomas express VH genes with a moderate number of antigen-selected somatic mutations. Am J Pathol 1995; 147:1398-407.

24. Marafioti T, Hummel M, Anagnostopoulos I, et al. Origin of nodular lymphocytepredominant Hodgkin's disease from a clonal expansion of highly mutated germinalcenter B cells. N Engl J Med 1997;337:453-8.

25. Giudicelli V, Chaume D, Lefranc MP. IMGTN-QUEST, an integrated software program for immunoglobulin and T cell receptor V-J and V-D-J rearrangement analysis. Nucleic Acids Res 2004;32(Web Server issue):W435-40.

26. Sims GP, Shiono H, Willcox N, et al. Somatic hypermutation and selection of B cells in thymic germinal centers responding to acetylcholine receptor in myasthenia gravis $\mathrm{J}$ Immunol 2001:167:1935-44.

27. Brezinschek HP, Foster SJ, Brezinschek Rl, et al. Analysis of the human VH gene repertoire. Differential effects of selection and somatic hypermutation on human peripheral $\mathrm{CD} 5(+) / \mathrm{lgM}+$ and $\mathrm{CD} 5(-) / \mathrm{lgM}+\mathrm{B}$ cells. J Clin Invest 1997:99:2488-501

28. Klein U, Goossens T, Fischer M, et al. Somatic hypermutation in normal and transformed human B cells. Immunol Rev 1998;162:261-80.

29. Becker YT, Samaniego-Picota M, Sollinger HW. The emerging role of rituximab in organ transplantation. Transp/ Int 2006;19:621-8.

30. Aranda JM Jr, Scornik JC, Normann SJ, et al. Anti-CD20 monoclonal antibody (rituximab) therapy for acute cardiac humoral rejection: a case report. Transplantation 2002:73:907-10. 
31. Alausa M, Almagro U, Siddiqi N, et al. Refractory acute kidney transplant rejection with CD20 graft infiltrates and successful therapy with rituximab. Clin Transplant 2005; 19:137-40.

32. Eikmans M, Roos-van Groningen MC, Sijpkens YW, et al. Expression of surfactant protein-C, S100A8, S100A9, and B cell markers in renal allografts: investigation of the prognostic value. J Am Soc Nephrol 2005:16:3771-86.

33. Desvaux D, Le Gouvello S, Pastural M, et al. Acute renal allograft rejections with major interstitial oedema and plasma cell-rich infiltrates: high gamma-interferon expression and poor clinical outcome. Nephrol Dial Transplant 2004:19:933-9.

34. Meehan SM, Domer P, Josephson M, et al. The clinical and pathologic implications of plasmacytic infiltrates in percutaneous renal allograft biopsies. Hum Pathol 2001;32:205-15.

35. Charney DA, Nadasdy T, Lo AW, et al. Plasma cell-rich acute renal allograft rejection. Transplantation 1999;68:791-7.

36. Gartner V, Eigentler TK, Viebahn R. Plasma cell-rich rejection processes in renal transplantation: morphology and prognostic relevance. Transplantation 2006:81:986-91.

37. Gloor JM, Sethi S, Stegall MD, et al. Transplant glomerulopathy: subclinical incidence and association with alloantibody. Am J Transplant 2007;7:2124-32.

38. Regele H, Exner M, Watschinger B, et al. Endothelial C4d deposition is associated with inferior kidney allograft outcome independently of cellular rejection. Nephrol Dial Transplant 2001;16:2058-66.

39. Artz MA, Steenbergen EJ, Hoitsma AJ, et al. Renal transplantation in patients with hemolytic uremic syndrome: high rate of recurrence and increased incidence of acute rejections. Transplantation 2003;76:821-6.
40. Colvin RB, Nickeleit V. Renal Transplant Pathology. 6th edn. Philadelphia: Lippincott Williams \& Wilkins, 2007.

41. Stott DI, Hiepe F, Hummel M, et al. Antigen-driven clonal proliferation of B cells within the target tissue of an autoimmune disease. The salivary glands of patients with Sjögren's syndrome. J Clin Invest 1998;102:938-46.

42. Hertz M, Kouskoff $\mathrm{V}$, Nakamura $T$, et al. V(D)J recombinase induction in splenic B lymphocytes is inhibited by antigen-receptor signalling. Nature 1998; 394:292-5.

43. Marafioti T, Hummel M, Anagnostopoulos I, et al. Classical Hodgkin's disease and follicular lymphoma originating from the same germinal center B cell. J Clin Oncol 1999;17:3804-9.

44. Ohno T, Trenn G, Wu G, et al. The clonal relationship between nodular sclerosis Hodgkin's disease with a clonal Reed-Sternberg cell population and a subsequent B-cell small noncleaved cell lymphoma. Mod Pathol 1998;11:485-90.

45. Petiniot LK, Weaver Z, Barlow C, et al. Recombinase-activating gene (RAG) 2-mediated $\mathrm{V}(\mathrm{D}) \mathrm{J}$ recombination is not essential for tumorigenesis in Atm-deficient mice. Proc Natl Acad Sci U S A 2000;97:6664-9.

46. Ohmori H, Hikida M. Expression and function of recombination activating genes in mature B cells. Crit Rev Immunol 1998;18:221-35

47. Hertz $\mathbf{M}$, Nemazee D. Receptor editing and commitment in B lymphocytes. Cur Opin Immunol 1998;10:208-13.

48. Marafioti T, Hummel M, Foss HD, et al. Hodgkin and Reed-Sternberg cells represent an expansion of a single clone originating from a germinal center B-cell with functional immunoglobulin gene rearrangements but defective immunoglobulin transcription. Blood 2000;95:1443-50. 